\title{
METHODS OF DRYING OF TOMATO SLICES AND THE EFFECT OF THE USING OF ITS POWDER ON THE PRODUCTION AND CHARACTERISTICS OF EXTRUDED SNACKS
}

\author{
${ }^{1}$ Farag Samia EL-Safy , ${ }^{2}$ Salem Rabab Hassan, \\ ${ }^{3}$ Younes Omar Shahat and ${ }^{4}$ Taha Samah Amin
}

\begin{abstract}
\end{abstract}
In this study, tomato samples were subjected to different pre-treatments (0.2\% sodium meta bisulphate $\left(\mathrm{Na}_{2} \mathrm{~S}_{2} \mathrm{O}_{5}\right), 1 \%$ calcium chloride $\left(\mathrm{CaCl}_{2}\right)$ and steam blanching. Untreated samples served as control. After pretreatment, tomato slices were subjected to three different drying methods (oven air, solar and microwave / hot air) and milled in grinder to powder. Tomato powder had been packed in multilayer films consists of low density polyethylene, aluminum and Polyester. Physical properties and bioactive compounds (total phenolic compounds, total flavonoids, $\beta$-carotene, lycopene, and ascorbic acid) of tomato powder were studied. The powder produced was used in functional food (extruded snacks). Dried tomato powder was added to corn grits flour at levels of 3 and $6 \%$ and extruded in a single screw extruder to produce healthy extrudes. Sensory characteristics and physical properties of snacks were evaluated. The studied parameter (moisture, total phenolic, total flavonoids lycopene and $\beta$-carotene) were significantly $(p \leq 0.05)$ affected by different pretreatments processes and drying methods. The results showed that solar drying had negative effect of all characteristics of tomato slices and the color was dark. The sensory analysis findings showed that, extrudes contain 3 and 6\% tomato powder (dried by oven and microwave/hot air) had significant higher color and taste scores. Adding tomato powder at level $6 \%$ led to increment in scores of crispness, flavor and overall acceptability.

Keywords: Tomatoes, pretreatments, drying methods, quality characteristics, snack food, extrusion, sensory evaluation

(1) Prof.and Head Food Science and Technology Dept., Faculty of Home Economic, Al- Azhar Univ.

(2) Senior Researcher Food Science and Technology Dept., Faculty of Home Economic, Al- Azhar Univ.

(3) Researcher,Food Manuf. Eng.and Pack. Res. Dept., Food Tech. Res.Inst.,Agriec.Res.Center.

(4) Research Assist. ${ }^{1}$ Food Science and Technology Dept., Faculty of Home Economic, Al- Azhar Univ. 


\section{INTRODUCTION}

7 Domato (Lycopersicum esculentum) is one of the major vegetables in the world, (FAOSTAT, 2010) indicates that the second most

1 cultivated vegetable in the world was tomato, which gave a worldwide production of more than 100 million $\mathrm{Mg}$ per annum. Tomatoes and tomato products are rich in health-related food components as they are good sources of carotenoids (in particular, lycopene), ascorbic acid, vitamin E, folate and total phenolic compounds. Dried tomato in the form of slices or powder helps to develop new food materials for ready to eat products. Many chemicals including sodium chloride, calcium chloride, potassium meta-bisulphite and sucrose had been used by many authors (Lewicki et al., 2002; Davoodi et al., 2007; Souza et al., 2007and Marfil et al., 2008) as pre-treatment for tomato drying. Convective hot air is the drying most widely used technology for vegetables with air temperature around $55^{\circ} \mathrm{C}$ and final moisture content of about 4-8\% as wet weight basis (Grabowski and Marcotte, 2003). Solar drying can be considered as an elaboration of sun drying and is an efficient system of utilizing solar energy. Microwave drying uses electromagnetic waves as a form of energy, which interacts with materials, thus generating heat and increasing the drying rate dramatically (Mujumdar, 1987). Food extrusion of breakfast cereals is defined as a cooking-extrusion process based on expanded, high voluminous, crispy and taste acceptable products extrudates (Hagenimana et al., 2005). This study was undertaken to investigation the effect of different pre-treatment processes (sodium meta-bisulphite, calcium chloride and steam blanching) and different drying methods (oven air, solar and microwave/ hot air) on the drying characteristics and some quality attributes of pre-treatments tomatoes. Study the possibility of using tomato powder in extruded products (snacks).

\section{MATERIALS AND METHODS}

\subsection{Materials}

Fresh tomato fruits (Lycopersicum esculentum) at ripe stage, uniform size, red colour and examined to exclude all virtual defects were purchased from local vegetable market at Al-Mansoura city, Egypt. Corn 
grits was purchased from Basyoun, El-Gharbia governorate, then ground to get homogenous particles size by using a laboratory mill to give powder (101-108 mesh). Palm Olean oil was obtained from Safola Company in the factor which prepared the snacks or products enrichment by tomato powders.

\subsection{Methods}

\subsubsection{Preparation of tomato slices}

Tomato fruits were washed manually under tap water to remove dirt and soils, and placed on plastic net to drain out excess water, sorted, then sliced to 5- $7 \mathrm{~mm}$ thickness slices using fruit slicer (HADDLE RG-400, Sweden) prior to pretreatment processes.

\section{Pre-Treatments given prior to dehydration process}

Tomato slices were divided into four groups and pre-drying treatments described subsequently were applied as follows: First group of slices were dipped into a solution of $0.2 \%$ sodium meta bisulfite solution (DMS) for $1 \mathrm{~min}$. Second group at slices were dipped into a solution of $1 \%$ Calcium chloride solution (DCC) for 1 min. Third group of slices were steamed under atmospheric pressure for $1 \mathrm{~min}(\mathrm{SB})$, then, tomato slices were drained on a sieve for 3-4 min. Four group slices were untreated as a control (C).

\subsubsection{Drying methods}

Three types of drying methods were applied: Hot air oven drying, Solar drying and microwave / air oven drying:

\section{Hot air oven drying}

Hot air drying process was performed by using a dryer (Venticell -lsis , modle number D 111004 /made in EU) .Tomato slices were distributed uniformly as a thin layer onto the trays and dried at $55^{\circ} \mathrm{C}$ for 8 hours (Balladin and Headley, 1999).

\section{Solar drying}

The dryer designed and manufactured by Ghanem (2002) in the roof of the Faculty of Agricultural Engineering - Al-Azhar University, Nasr City. Was used; the drying process was carried out at $40^{\circ} \mathrm{C}$. 


\section{Microwave drying}

Microwave /convection dryer consists of: domestic microwave oven, air blower, electrical heater and electrical balance Tayel etal (2012).

Was used the dried tomato slices of all drying methods were milled in a grinder to powder then been packed in the multilayer containers consist of( polyester / aluminum / low density polyethylene) ( PES./ AL./ PE.).

\subsubsection{Analytical methods}

\subsubsection{Physical characteristics}

The dehydration ratio was determined as described by (Van-Arsdel et al., 1973), as $\frac{\text { Weight of wet weight slices }}{\text { Weight of slices after drying }}$. The rehydration ratio of dried tomato samples was calculated as the method of (Ranganna , 1979), as $\frac{\text { Weight of rehydrated sample }}{\text { Weight of dehydrated sample }}$,Moisture content using hot air oven at $105^{\circ} \mathrm{C}$ to constant weight according to the methods described in(A.O.A.C. 2005).

\subsubsection{Phytochemical compounds}

The total phenolic compounds presented in the extracted tomato samples were determined spectrophotometrically using Folin - Ciocalteu reagent according to the method described by (Gorinstein $\boldsymbol{e t}$ al., 1994). Total flavonoids were determined according to the method described by (Zhuang et al., 1992). The method described by Nagata and Yamashita (1992) was used for the determination of $\beta$-Carotene and lycopene. Ascorbic acid content was estimated using 2,6-dichlorophenol indophenol titration method according to the method described by (A.O.A.C., 2005).

\subsubsection{Extrusion technology}

\subsubsection{Sample preparation}

In the extrusion process, the dry or pre-conditioned material (corn grits and tomato powder generally between $14-18 \%$ moisture content) was fed to the extruder through a screw feeder, temperature $\left(160-180^{\circ} \mathrm{C}\right)$ and pressure $(600-1200 \mathrm{k}$ Pascal $)$. A single die with $3 \mathrm{~mm}$ diameter was used as the die is a perture. Pre-conditioning occurred with addition of water to reach $14-18 \%$ moisture content. The main aim of preconditioning process is to uniformly hydrate the raw material in order to 
eliminate any dry corn (Strahm, 2000). Feed was prepared for the extrusion process by mixing tomato powder with corn grits flour (to desired ratio: $0 \%$ as a control, $3 \%$ and $6 \%$ tomato powder) to the moisture content of $14-18 \%$. The sublimation of tomato powders to corn grits flour were done by two methods: The first one, tomato powder was added with formulation and the second, tomato powder was dissolved in oil and added in spray form on the resultant extrudates immediately after getting out of the extruder. The feed rate of dry ingredients was kept constant at $120 \mathrm{~kg} / \mathrm{hr}$, screw power was $45 \mathrm{~kW}$. and water feed rate was $0.51 / \mathrm{h}$. The resultant extrudates were allowed to reach room temperature and packed in multilayer films consists of low density polyethylene, aluminum and Polyester sealed bags until physical and sensory evaluation were carried out.

\subsubsection{Physical properties of snack products}

Shear force $(\mathrm{N})$ was measured by food texture a device and viscosity was used to determine the texture of the extruded, according to the method of (Gujska and Khan, 1991). WAI was assessed as described by (Anderson et al., 1999). The water solubility index (WSI) was determined as [(weight of dried supernatant) / (weight of dry sample) $\times 100]$.

\section{(Anderson et al., 1999).}

\subsubsection{Sensory evaluation}

The sensory evaluation of the resultant snack prepared from tomato powders was carried out after processing. All panelists were from the cast of Food Technology Research Institute, Agriculture Research Center. Five properties: color, taste, crispness, flavor and overall acceptability of the samples were measured as described by (Kramer and Twigg, 1970).

\subsubsection{Statistical analysis}

The experiments were performed using a completely randomized design. All analysis were performed with SPSS (SPSS. Inc., Chicago, IL, USA).The data were analyzed $\log$ one way analysis of variance (ANOVA). Means separation was performed by Duncan (1955) triple range tests. Differences at $p<0.05$ were considered as significant. 


\section{RESULTS AND DISCUSSION}

\subsection{Effect of pretreatments and drying methods on drying behavior of tomato slices}

\subsubsection{Oven drying methods}

Data in Figure (1) indicates that the moisture content versus drying time for tomato slices by oven air varied depending on the pretreatments processes before drying methods. During the process of drying the moisture content of control tomato slices is reduced to $\leq 10 \%$ (w.b.) Figure (1) is exhibiting a non-linear decrease of moisture with drying time.This refers to the increase of evaporation rate in the beginning of drying process.

Fig. (1) shows that the drying time of tomato slices treated with sodium meta-sulphate had been achieved by sodium meta-bisulfite was 9 hours to reach moisture content of $10 \%$,while the drying time of tomato slices treated with Calcium Chloride and also steam blanching was 10 hours to reach the same moisture content.

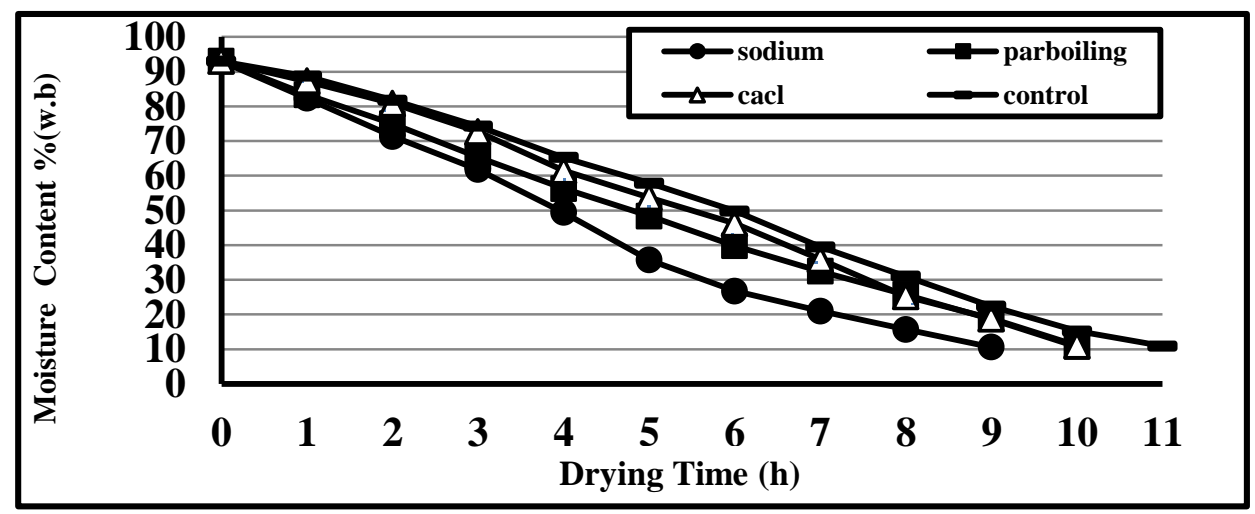

Fig (1):Moisture content \% (w.b) versus drying time of pretreated tomato slices during oven drying.

Figure (2) shows that the highest drying rate had been achieved by sodium meta-bisulfite and steam blanching treatments as $10.68 \%$ in 9 hours as the shortest drying time compared with other treatments . Drying rate in case of Calcium chloride treatment was $5 \%$ in 10 hours each . 
Sharma et al., (2005) reported that absorption of more energy by the water at the product surface initially, resulting in faster drying and with the product surface drying out subsequently, heat penetration through the dried layer decreased thus retarding the drying rates. Pretreatments can speed up drying rate (Jayaraman and Gupta, 2006and Singh et al, 2008).

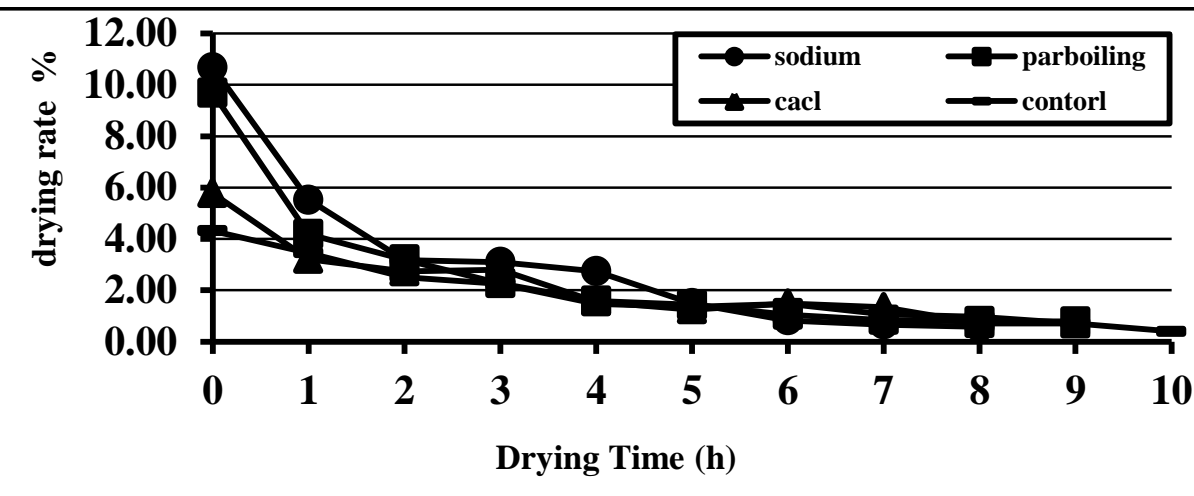

Fig (2 ):Drying rate of pretreated tomato slices versus drying time during oven drying.

\subsubsection{Solar drying}

The measured moisture content for the solar dried tomato slices were tabulated in Fig. (3)that shows the general trend of drying rate decreases continuously with decreasing moisture content. (Yaldiz, 2001; Togrul and Pehlivan, 2002). Akpinar et al. (2003) reported that the migration of moisture to surface and evaporation rate from surface to air decreases with decrease of moisture in the product, the drying rate clearly decreases. Gazenfer and Sefa (2006) and Doymaz, (2004) showed that chemical pretreatment could significantly accelerate the drying process and remarkably improve the quality of dried products .

Fig.(3) shows that as a general trend the evaporation rate of tomato slices increases by the increase of solar radiation intensity during drying period. Where the drying time of tomato slices treated with sodium meta sulphate and steam blanching was 26 hours to reach moisture content of $10 \%$, while the drying time of tomato slices treated with Calcium Chloride was 28 hours to reach the same moisture content. 


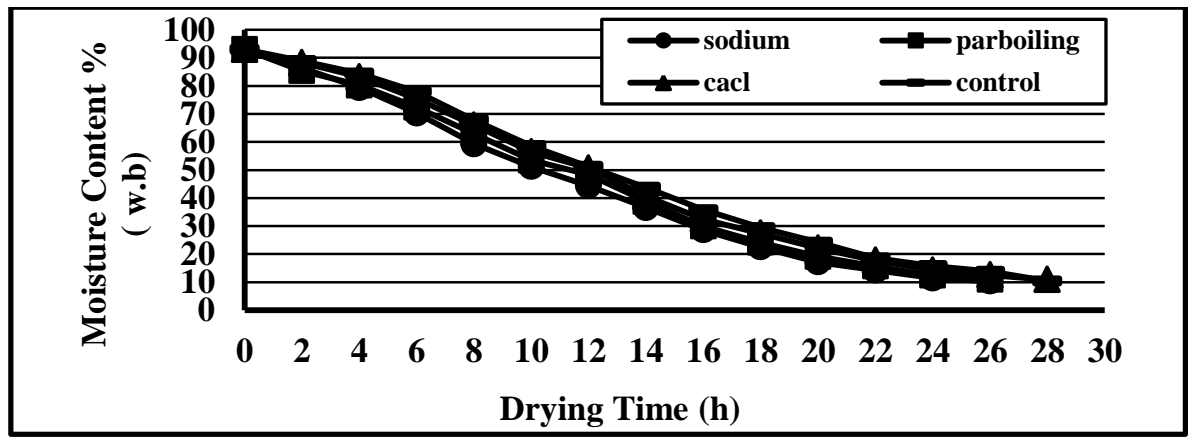

Fig.(3):Moisture content (\%) of pretreated tomato slices versus drying time during solar drying.

Fig. (4), observes that the drying rate increased rapidly during the first 10 hours. Then slowed down. Hussain et al. (1972). stated that high moisture foods usually have falling rate period drying only. This may be attributed to low diffusion of moisture within the tomato slices than that of evaporation of moisture from the surface.

Figure (4) also shows that the highest drying rate had been achieved by sodium meta- bisulfite and steam blanching treatment as $3.35,3.82 \%$ in 26 hours as the shortest drying time compared with other treatment .

Drying rate in case of Calcium Chloride treatment was $2.39 \%$ in 28 hours each .

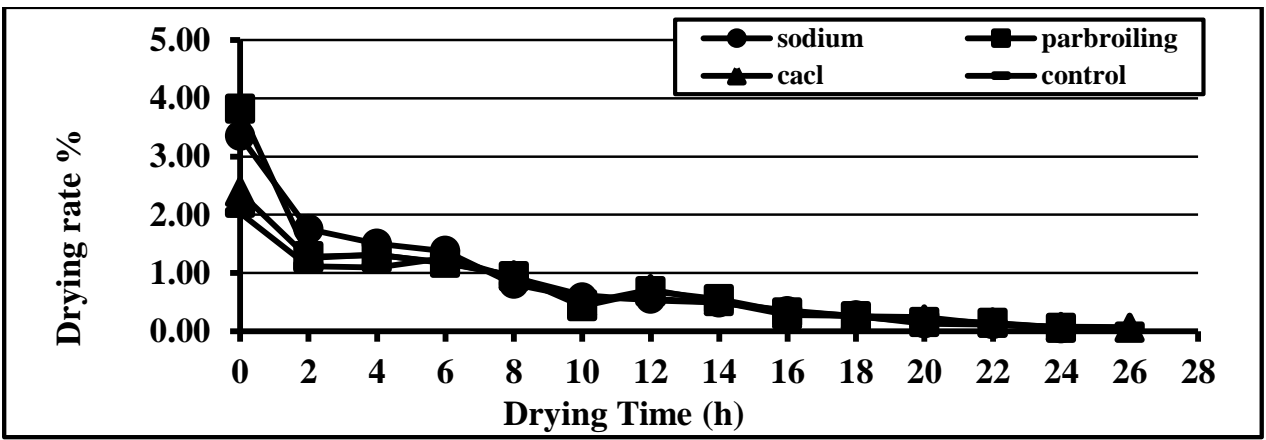

Fig.(4):Drying rate of pretreated tomato slices versus drying time during solar drying.

\subsubsection{Microwave/hot air drying methods}

it has been using radiation intensity of 160 watt at a temperature of $50 \mathrm{C}^{\circ}$ Results presented in Fig. (5), indicated that the moisture content decreases continuously with drying time. The drying time varied between 80 - 100 min to reach of $10 \%$ moisture content .Where the drying time of 
tomato slices treated with sodium meta-sulphate and steam blanching was $80 \mathrm{~min}$, to reach moisture content $10 \%$, while the drying time of tomato slices treated with Calcium Chloride was 90 min to reach the same moisture content.In control (without pretreatment). For microwave oven drying, the drying time was $80 \mathrm{~min}$, to reach moisture content $10 \%$ (wb). Heat is generated when microwave interacts with the polar water molecules in fruits and vegetables and significantly high drying rate was achieved when compared to air drying alone (Schiffmann, 1992). The treated tomato slices dried faster than the control at $50^{\circ} \mathrm{C}$. Increased moisture removal for Calcium Chloride treated dried tomato as reported by (Davoodi et al., 2007; Ghavidel and Davoodi, 2010).

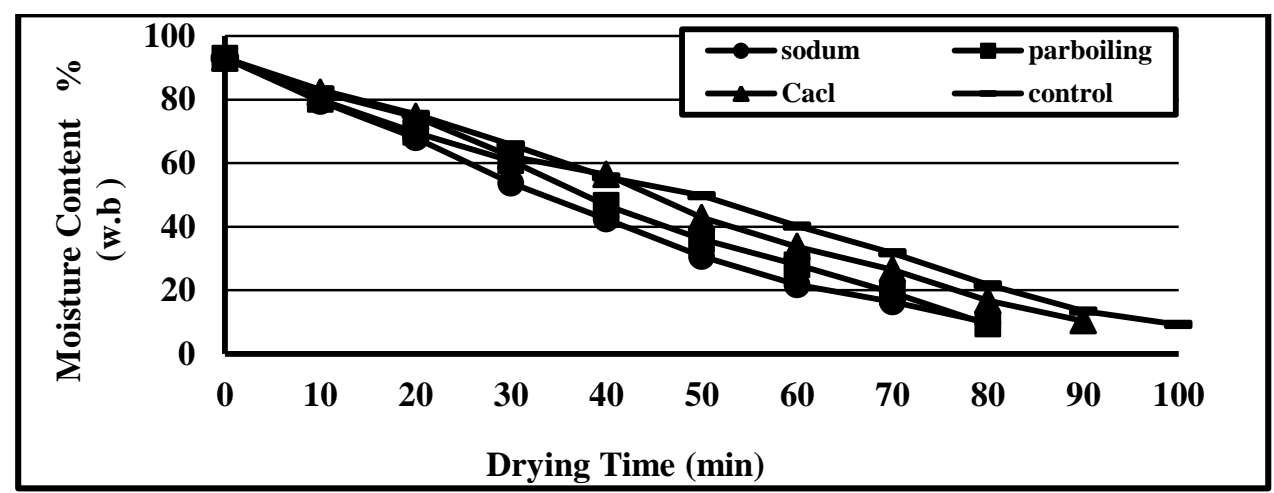

Fig.(5):Moisture content (\%) of pretreated tomato slices versus drying time during microwave/hot air drying.

Drying rate curve for dried tomato slices showing the effect of pretreatment during microwave/hot air drying are presented in Figure (6). Generally, drying rates decreased with decreasing moisture contents, and drying occurred in the falling rate period. Doymaz (2004) reported that faster drying rate for citric acid treated red apples compared with the control.Where the drying time of tomato slices treated with sodium meta - sulphate and steam blanching was $80 \mathrm{~min}$, to reach drying rates 1.3 1.38 ,while the drying time of tomato slices treated with Calcium Chloride was $90 \mathrm{~min}$ to reach 1.1. In control (without pretreatment). For microwave oven drying, the drying time was $80 \mathrm{~min}$, to reach drying time 1. 


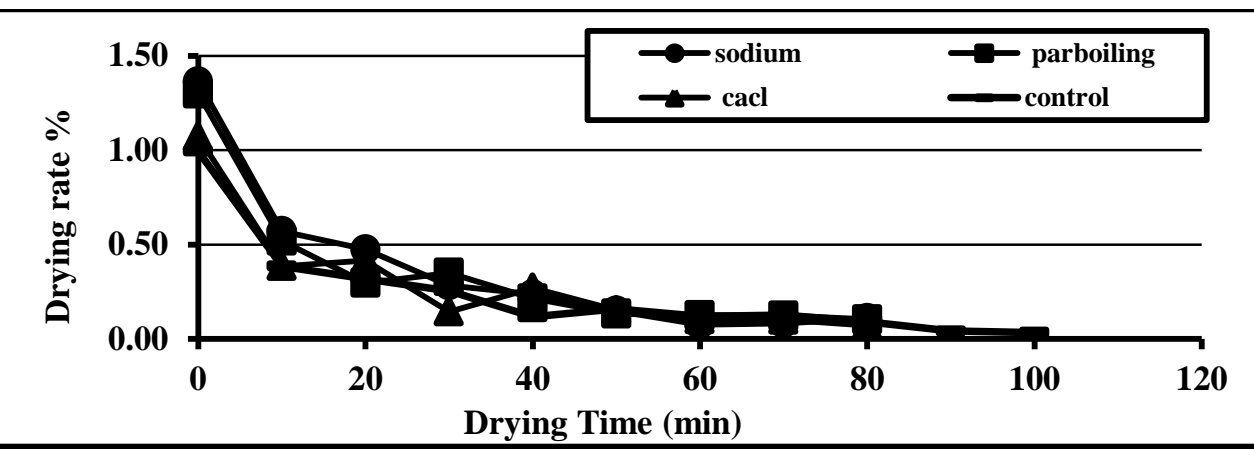

Fig.(6):Drying rate versus drying time of pretreated tomato slices during microwave/hot air drying.

\subsection{Effect of pretreatments and drying methods on physical properties of tomato slices}

Data in Table (1) shows the effect of different pretreatment processes on dehydration ratio of tomato slices reveal that DCC treated tomato samples showed lowest dehydration ratio as compared to sodium metabisulphite or steam blanching treatments.

Table (1):Dehydration and rehydration ratio of pretreated tomato slices dried by three different methods

\begin{tabular}{|c|c|c|}
\hline $\begin{array}{c}\text { Pretreatment/ } \\
\text { Dehydration } \\
\text { methods }\end{array}$ & Dehydration ratio & Rehydration ratio \\
\hline Air Oven & $15.11^{\mathrm{ab}}$ & $4.63^{\mathrm{bc}}$ \\
DMS & $14.50^{\mathrm{b}}$ & $4.89^{\mathrm{bc}}$ \\
DCC & $14.62^{\mathrm{b}}$ & $6.92^{\mathrm{a}}$ \\
SB & $15.75^{\mathrm{a}}$ & $4.21^{\mathrm{c}}$ \\
Control & $15.40^{\mathrm{ab}}$ & $4.02^{\mathrm{c}}$ \\
\hline Solar Oven & $14.68^{\mathrm{ab}}$ & $4.94^{\mathrm{bc}}$ \\
\hline DMS & $14.92^{\mathrm{b}}$ & $5.09^{\mathrm{bc}}$ \\
DCC & $15.66^{\mathrm{a}}$ & $4.11^{\mathrm{c}}$ \\
SB & $15.45^{\mathrm{ab}}$ & $4.48^{\mathrm{bc}}$ \\
Control & $14.41^{\mathrm{c}}$ & $5.16^{\mathrm{ac}}$ \\
\hline Microwave/hot air & $15.72^{\mathrm{a}}$ & $6.14^{\mathrm{ab}}$ \\
\hline DMS & $15.78^{\mathrm{a}}$ & $3.77^{\mathrm{c}}$ \\
DCC & SB & \\
Control & & \\
\hline
\end{tabular}

DMS= dipping in $0.2 \%$ sodium meta bisulphite solution

DCC = dipping in $1 \%$ calcium chloride solution

SB = Steam blanching

Values with in a column followed by different letters are significantly differently at $p \leq 0.05$. a according to Danken's multiple range tests. The results represent the mean of three determinations. 
These results are complied with Sheshma and Raj, (2014) who reported that treatment of tomato slices with calcium of cut tissue reduces its respiration. It is clear from tabulated data that rehydration ratio is significantly $(\mathrm{p} \leq 0.05)$ affected by chemical pretreatment. The rehydration ratio ranged between 4.017 to 6.9237 which were affecting significantly $(\mathrm{p} \leq 0.05)$ by the pretreatments. $\mathrm{CaCL}_{2}$ and sodium meta-bisulphiate had desirable effects on rehydration properties of the dehydrated tomatoes; while control sample showed the lowest values of rehydration ratio. From the tabulated data, it could be noticed that steam blanching treatment improved the rehydration values of all dried tomato slices. Similar results obtained by Levi et al., (1988) who demonstrated that dried peach fruit samples treated before dehydration with $\mathrm{So}_{2}$ absorb more water than control ones. From the above mentioned results it could be concluded that tomato slices treated by steam blanching as pretreatment had the highest rehydration ratio which recorded 6.92, 5.09 and 6.1 for dried tomato slices by oven air, solar and microwave (hot air drying) respectively.

\subsection{Effect of pretreatments and drying methods on phytochemical compounds of tomato powders}

In Table (2), total phenolic contents of fresh tomatoes were significantly lower (105.57 mg gallic acid $/ 100 \mathrm{~g}$, DM), than dried tomato slices samples. The highest phenolic content was found in tomato slices dried by oven air $\left(55^{\circ} \mathrm{C} / 8\right.$ hours $)$ and treated with sodium meta-bisulphite (302.99 $\mathrm{mg}$ gallic acid/100gm) compared to tomato slices dried by solar drying or microwave /hot air drying . These results are in agreement with Kim et al., (2006). The effects of pretreatment on total flavonoids content of dehydrated tomato slices during drying by different methods were presented in Table (2). Results showed that pretreatment with steaming and sodium meta-bisulphite increased total flavonoids in tomato slices compared with $\mathrm{CaCl}_{2}$ treatment. Also, Chang et al. (2006) indicated that the drying process could enhance the nutritional value of tomatoes by increasing parts of total flavonoids, total phenolic, lycopene contents. Data presented in Table (2), appeared that tomato slices pretreated with sodium meta-bisulphite showed higher values of $\beta$ - 
carotene than the control samples followed by treated samples by calcium chloride $\left(\mathrm{CaCl}_{2}\right)$. The lowest value of $\beta$ - carotene was found in control samples. These results were in according with those reported by Ghavidel and Davoodi (2010) who reported that potassium metabisulphite is used to protect the carotenoid pigments and color retention in dehydration of tomato.

Table(2):Effect of pretreatment and drying methods on phytochemical compounds of tomato slices.

\begin{tabular}{||c|c|c|c|c|c||}
\hline Compounds & $\begin{array}{c}\text { Total } \\
\text { phenolic } \\
\text { compounds } \\
(\mathrm{mg} / 100 \mathrm{~g})\end{array}$ & $\begin{array}{c}\text { Total } \\
\text { flavonoids } \\
(\mathrm{mg} / 100 \mathrm{~g})\end{array}$ & $\begin{array}{c}\beta \text { - carotene } \\
(\mathrm{mg} / 100 \mathrm{~g})\end{array}$ & $\begin{array}{c}\text { Lycopene } \\
(\mathrm{mg} / 100 \\
\mathrm{g})\end{array}$ & $\begin{array}{c}\text { Ascorbic acid } \\
(\mathrm{mg} / 100 \mathrm{~g})\end{array}$ \\
\hline $\begin{array}{c}\text { Oven air } \\
\text { DMS }\end{array}$ & $343.57^{\mathrm{b}}$ & $388.00^{\mathrm{d}}$ & $35.26^{\mathrm{a}}$ & $42.61^{\mathrm{a}}$ & $25.33^{\mathrm{e}}$ \\
DCC & $311.26^{\mathrm{cd}}$ & $385.50^{\mathrm{e}}$ & $29.24^{\mathrm{b}}$ & $31.16^{\mathrm{c}}$ & $22.71^{\mathrm{f}}$ \\
SB & $289.20^{\mathrm{g}}$ & $474.88^{\mathrm{a}}$ & $24.40^{\mathrm{d}}$ & $24.43^{\mathrm{d}}$ & $18.89^{\mathrm{gh}}$ \\
Control & $243.16^{\mathrm{k}}$ & $100.76^{\mathrm{k}}$ & $15.66^{\mathrm{g}}$ & $20.72^{\mathrm{e}}$ & $16.74^{\mathrm{ij}}$ \\
\hline Solar & & & & & \\
DMS & $302.99^{\mathrm{f}}$ & $346.74^{\mathrm{h}}$ & $24.69^{\mathrm{d}}$ & $17.88^{\mathrm{f}}$ & $20.52^{\mathrm{g}}$ \\
DCC & $288.33^{\mathrm{g}}$ & $385.57^{\mathrm{e}}$ & $20.61^{\mathrm{e}}$ & $15.25^{\mathrm{g}}$ & $18.34^{\mathrm{hi}}$ \\
SB & $285.76^{\mathrm{h}}$ & $404.99^{\mathrm{b}}$ & $18.31^{\mathrm{f}}$ & $15.36^{\mathrm{g}}$ & $12.74^{\mathrm{k}}$ \\
Control & $256.34^{\mathrm{j}}$ & $201.36^{\mathrm{j}}$ & $12.66^{\mathrm{h}}$ & $12.52^{\mathrm{h}}$ & $15.82^{\mathrm{j}}$ \\
\hline Microwave & & & & & \\
DMS & $312.84^{\mathrm{c}}$ & $371.70^{\mathrm{f}}$ & $27.97^{\mathrm{bc}}$ & $22.96^{\mathrm{d}}$ & $46.67^{\mathrm{b}}$ \\
DCC & $306.54^{\mathrm{e}}$ & $366.15^{\mathrm{g}}$ & $27.29^{\mathrm{c}}$ & $16.14^{\mathrm{g}}$ & $29.67^{\mathrm{d}}$ \\
SB & $310.08^{\mathrm{d}}$ & $391.12^{\mathrm{c}}$ & $21.92^{\mathrm{e}}$ & $15.40^{\mathrm{g}}$ & $33.00^{\mathrm{c}}$ \\
Control & $266.10^{\mathrm{i}}$ & $276.19^{\mathrm{i}}$ & $14.18^{\mathrm{gh}}$ & $14.78^{\mathrm{g}}$ & $28.45^{\mathrm{e}}$ \\
\hline
\end{tabular}

DMS= dipping in $0.2 \%$ sodium meta-bisulphite solution DCC = dipping in $1 \%$ calcium chloride solution SB $=$ Steam blanching

Values with in a column followed by different letters are significantly differently at $p \leq 0.05$. a according to Danken's multiple range tests. The results represent the mean of three determinations.

Solar dried tomato slices had the lowest $\beta$-carotene content probably due to the long drying period of tomato slices in solar drier (28 hour) or to some oxidation reactions. From the tabulated data, it could be noticed that lycopene content in dehydrated tomato slices was influenced by drying methods. More lycopene degradation was observed in control samples comparing with treated tomato slices. Stahl and Sies (1992) suggested that a greater content of lycopene was found in heat processed tomato juice than in unprocessed one. On the other hand, Table (2), it 
could be noticed that ascorbic acid content (mg/100g) differ in the different dried tomato slices. In this concept, tomato slices treated by steaming and dried recorded the highest decrease of ascorbic acid. Tomato slices treated with sodium meta-bisulphite minimized the effect of drying process on ascorbic acid. These results are in agreement with those reported by Mattuk et al. (1997) who showed that guava slices soaked in sodium meta-bisulphite solution decreased the loss of ascorbic acid content caused by dehydration. Also from the same Table .vitamin $\mathrm{C}$ content of fresh tomato was $405.85 \mathrm{mg} / 100 \mathrm{~g}$ (on dry weight basis), decreased after drying process and the decrement was sharply higher in tomato slices dried by solar drying comparing with oven air or microwave- hot air.

\subsection{Physical properties of extruded snacks prepared from tomatoes powder}

Expansion is an important physical attribute for the extruded snacks that greatly affects consumer acceptability (Dehghan-Shoar et al., 2010). As shown in Table (3), incorporation of tomatoes powder (which dried by oven air and microwave/hot air at level 3 and 6\%) reduced the expansion ratio compared to control (without addition tomato powder). Higher levels of dried tomatoes powder $(6 \%)$ resulted in significant reduction of the expansion. The extruded product contained 3\% tomato powder which was dried by oven air had expansion ratio 5.24, raising the ratio of this supplement to $6 \%$ in blends lowered this value to 4.49. Moraru and Kokini (2003) reported that the expansion of extruded products is enhanced by increases in temperature to an optimum point and then it decreases. This temperature depends on the ingredients used. It may be possible that a temperature of $160^{\circ} \mathrm{C}$ for products was this optimum point and after this point the expansion decreased with an increase in temperature which resulted in the overall insignificant effect of the temperature on expansion. From the tabulated data, it could be observed that control had the highest value of expansion ratio which recorded 5.40 followed by the formula contain $3 \%$ tomatoes powder. This results are in agreement with Morsy et al., (2015) who reported that maximum expansion ratio was obtained for rice bran (control), due to the higher starch and lower fiber and fat contents. Yanniotis et al., (2007) observed 
that the powders high in fiber content have competed for moisture during the extrusion process affecting the degree of gelatinization and therefore the degree of expansion. Water absorption index decreased with increase in moisture content, which may be attributed to the reduction of elasticity of dough through plasticization of melt at higher moisture content (Ding et al., 2006). The highest values of water absorption were recorded in control snacks $(6.40 \%)$ and formulation contained $6 \%$ tomato powder (which dried by oven and microwave/hot air) (5.70 and 5.70\%, respectively. Matthey and Hanna (1997) reported that water absorption depends on availability of hydrophilic groups which bind water molecules and on the gel forming of macromolecules. Water absorption index increased with the increase in high temperature probably due to increased dextrinization higher temperature (Mercier and Feillet, 1995). The water solubility index increased initially with the increase in moisture content, which may be due to proper gelatinization and lateral expansion of the starch, whereas further decrease with the increase in moisture content may be attributed to reduction in lateral expansion due to plasticization of melt as observed by Ding et al., (2005). From the results recorded in Table (3) the incorporation of tomato powders significantly $(\mathrm{p} \leq 0.05)$ influenced the water solubility. The increase of dried tomato powder level decreased the water solubility (\%), that may be due to-increased the fiber content in resultant extrudes.

Table (3):Physical properties of extruded snacks as affected by using tomatoes powder

\begin{tabular}{|c|c|c|c|c||}
\hline Treatment & $\begin{array}{c}\text { Expansion } \\
\text { ratio }\end{array}$ & $\begin{array}{c}\text { Shear force } \\
\text { (Neutin) }\end{array}$ & $\begin{array}{c}\text { Water } \\
\text { absorption }(\%)\end{array}$ & $\begin{array}{c}\text { Water solubility } \\
(\%)\end{array}$ \\
\hline FORM 1 & $5.24 \mathrm{~b}$ & $3.60 \mathrm{~b}$ & $5.20 \mathrm{~d}$ & $31.60 \mathrm{e}$ \\
\hline FORM 2 & $4.94 \mathrm{c}$ & $3.60 \mathrm{~b}$ & $5.50 \mathrm{c}$ & $40.0 \mathrm{~d}$ \\
\hline FORM 3 & $4.50 \mathrm{~d}$ & $2.50 \mathrm{c}$ & $5.70 \mathrm{~b}$ & $46.0 \mathrm{c}$ \\
\hline FORM 4 & $4.10 \mathrm{e}$ & $2.40 \mathrm{c}$ & $5.70 \mathrm{~b}$ & $47.0 \mathrm{~b}$ \\
\hline Control & $5.40 \mathrm{a}$ & $6.10 \mathrm{a}$ & $6.40 \mathrm{a}$ & $55.80 \mathrm{a}$ \\
\hline
\end{tabular}

FORM $_{1}=$ formulation with $3 \%$ tomatoes powder dried by oven air

FORM $_{2}=$ formulation with $3 \%$ tomatoes powder dried by microwave/hot air

FORM $_{3}=$ formulation with $6 \%$ tomatoes powder dried by oven air

FORM $_{4}=$ formulation with $6 \%$ tomatoes powder dried by microwave/hot air

Values with in a column followed by different letters are significantly differently at $p \leq 0.05$. a according to Danken's multiple range tests. The results represent the mean of three determinations 


\subsection{Sensory evaluation}

As shown in Table (4), the highest color value was 9.26 in formula supplemented with $6 \%$ tomato powder which dried by microwave/hot air and added after extrusion process by spraying on the product, while sample contained $6 \%$ tomato powder dried by oven air and microwave/hot air and added during preparation of formula had the lowest color score 6.47 and 6.68, respectively. Color in extruded products is influenced by temperature, raw material composition, residence time, pressure and shear force (Guy, 2001).

Table (4): Sensory evaluation of extruded snacks as affected by using tomatoes powder.

\begin{tabular}{|c|c|c|c|c|c|}
\hline Treatment & $\begin{array}{c}\text { Color } \\
(10)\end{array}$ & $\begin{array}{c}\text { Taste } \\
(10)\end{array}$ & $\begin{array}{c}\text { Crispness } \\
(10)\end{array}$ & $\begin{array}{c}\text { Flavor } \\
(10)\end{array}$ & $\begin{array}{c}\text { Overall } \\
\text { acceptability } \\
(10)\end{array}$ \\
\hline FOB 3\% & $7.26 \mathrm{de}$ & $6.39 \mathrm{c}$ & $7.03 \mathrm{~b}$ & $6.58 \mathrm{bc}$ & $6.92 \mathrm{cde}$ \\
\hline FOB 6\% & $6.47 \mathrm{~d}$ & $5.58 \mathrm{c}$ & $7.89 \mathrm{abc}$ & $8.00 \mathrm{a}$ & $7.76 \mathrm{abc}$ \\
\hline FMB 3\% & $7.03 \mathrm{de}$ & $6.11 \mathrm{c}$ & $7.37 \mathrm{bc}$ & $7.89 \mathrm{a}$ & $8.11 \mathrm{ab}$ \\
\hline FMB 6\% & $6.68 \mathrm{~d}$ & $6.06 \mathrm{c}$ & $8.50 \mathrm{a}$ & $7.55 \mathrm{ab}$ & $8.50 \mathrm{a}$ \\
\hline FOA 3\% & $8.13 \mathrm{bc}$ & $7.53 \mathrm{ab}$ & $7.74 \mathrm{abc}$ & $6.89 \mathrm{abc}$ & $7.11 \mathrm{cde}$ \\
\hline FOA 6\% & $8.50 \mathrm{abc}$ & $7.76 \mathrm{a}$ & $7.00 \mathrm{~b}$ & $6.05 \mathrm{~cd}$ & $6.47 \mathrm{de}$ \\
\hline FMA 3\% & $8.79 \mathrm{ab}$ & $8.06 \mathrm{a}$ & $8.00 \mathrm{ab}$ & $5.42 \mathrm{~d}$ & $6.21 \mathrm{e}$ \\
\hline FMA 6\% & $9.26 \mathrm{a}$ & $8.55 \mathrm{a}$ & $7.68 \mathrm{abc}$ & $6.89 \mathrm{abc}$ & $7.47 \mathrm{abc}$ \\
\hline Control & $7.74 \mathrm{~cd}$ & $6.61 \mathrm{bc}$ & $8.47 \mathrm{a}$ & $7.53 \mathrm{ab}$ & $7.58 \mathrm{abc}$ \\
\hline
\end{tabular}

FOB = Tomato powder dried by oven and added in formulation (before extrusion)

FMB = Tomato powder dried by microwave and added in formulation (before extrusion)

FOA = Tomato powder dried by oven and added after extrusion by spraying

FMA = Tomato powder dried by microwave and added after extrusion by spraying

Values with in a column followed by different letters are significantly differently at $p \leq 0.05$. a according to Danken's multiple range tests.

During the extrusion process, several reactions happen and they in general affect the color of the products. Among the most important, the most common are non-enzymatic browning (Maillard and caramelization) and pigment degradation. The extrusion temperature and amount of moisture added to the dry ingredient formula will greatly affected the structure of the final product texture and density. Noguchi $\boldsymbol{e t}$ 
al, (2001) reported that product crispiness increased as moisture content decreased during extrusion of rice/soy protein concentrate blend. Wang and Toews (2010) reported that, the quality of expanded snacks depends on many factors, such as raw ingredients, formulation and processing conditions, starch which play very importance of the final product depending on the type of product, starches and their derivatives can provide viscosity and texture control, act as moisture binder and facilitate the processing procedure. Adding 3 and $6 \%$ tomato powder dried by microwave/hot air in formula with corn grits enhanced overall acceptability which recorded 8.11 and 8.50 score, respectively. Dehghan-Shoar et al. (2010) reported that enrichment of extruded snacks with tomato derivatives enhances their nutritional attributes by adding lycopene and fiber.

\section{CONCLUSION}

Treatment by $0.2 \%$ sodium meta-bisulphite enhanced removal moisture in tomato slices by three drying methods. Drying rate decreased by decreasing moisture content or increasing drying time. Pretreatment processes (dipping in $1 \% \mathrm{Na}_{2} \mathrm{~S}_{2} \mathrm{O}_{5}$ sodium meta-bisulphite solution or $1 \% \mathrm{CaCl}_{2}$ solution and steam blanching) had effect on dehydration and rehydration ratios of dried tomato slices. Steam blanching treatment improved the rehydration values of all dried tomato slices. Tomato fruits were rich in bioactive compounds such as total phenolic compounds, total flavonoids, $\beta$ - carotene, lycopene and ascorbic acid which affected by both pretreatment processes and different drying methods. The results indicated that drying methods increased total phenolic compounds, total flavoneds, lycopene and sharply decreased ascorbic acid. The sensory analysis findings showed that, extrudes contain 3 and $6 \%$ tomato powder (dried by oven and microwave/hot air) had significant higher color and taste scores. Adding tomato powder at a level 6\% led to increment in scores of crispness, flavor and overall acceptability.

\section{REFERENCES}

A.O.A.C. (2005). Association of Official Method of Analysis, $18^{\text {th }}$ Ed. of A.O.A.C. International. Published by A.O.A.C. International, Washington, USA. 
Akpinar, E.; Midilli, A. and Y. Bicer, (2003). Single layer drying behavior of potato slices in a convective cyclone dryer and mathematical modeling. Energy Conversion and Management 44(10):1689-1705.

Anderson, Y.; Hedlund, B.; Jonsson, L. and S. Svensson, (1999). Extrusion cooking if a high fiber cereal product with crisp-bread character. Cereal Chem., 58(5): 370-374.

Balladin, D. and O. Headley, (1999). Evaluation of solar dried thyme (Thymus vulgaris Linne.) herbs. Renewable Energy, 17: 523-531.

Chang, C.; Lin, H.; Chang, C. and Y. Liu, (2006). Comparisons on the antioxidant properties of fresh, freeze-dried and hot-air-dried tomatoes. J. Food Eng., 77: 478-485.

Davoodi, M.; Vijayanand, P.; Kulkari, S. and K. Ramana . (2007). Effect of different pre-treatments and dehydration methods on quality characteristics and storage stability of tomato powder. LWT-Food Sci. and Techno., 40: 1832- 1840.

Ding, Q.; Ainsworth, P.; Tucker, G. and H. Marson, (2005). The effect of extrusion conditions on the physicochemical properties and sensory characteristics of rice-based expanded snacks. J Food Eng., 66: 283-289.

Dehghan-Shoar, Zeinab; Hardacre, A. and C. Brennan, (2010). The physicochemical characteristics of extruded snacks enriched with tomato lycopene. Food Chem., 123 (4): 1117 - 1122.

Ding, Q.-; Ainsworth, P.; Plunkett, A.; Tucker, G. and H. Marson, (2006). The effect of extrusion conditions on the functional and physical properties of wheat-based expanded snacks. J. Food Eng., 73(2): 142-148.

Doymaz, I.(2004). Pretreatment effect on sun drying of mulberry fruits (Morus alba L). J. Food Eng., 65: 205-209.

Duncan, D. (1955). Multiple range and multiple F-test.Biommetric, 11: 1-42. Edition ASSOC. Office. Anal. CHem. Arlington.

FAOSTAT (2010). http://faostat.fao.org/site/1367/Default. aspx. Accessed: 24.02.2011. 
Gazenfer, E. and T. Sefa, (2006). Colour retention of red peppers by chemical pretreatment during greenhouse and open sun drying. J. Food Eng., 76: 446- 452.

Ghanem, M. (2002). Thin layer solar drying of shelled corn. The $10^{\text {th }}$ annual conference of the Egypt Society of Agric. Eng., pp: $16-$ 17 October 282- 292.

Ghavidel, R. and M. Davoodi, (2010). Studies on physicochemical properties of tomato powder as affected by different dehydration methods and pretreatments. World Academy of Sci, Eng. and Technol., 69: 596 - 605.

Grabowski, S. and M. Marcotte, (2003). Drying of fruits and vegetables and spices. In Handbook of postharvest Technology: Cereals, Fruits, Vegetables, Tea and Spices, eds. Chakraverty. A., A.S. Mujumdar, G.S.V. Raghavan and H.S. Ramaswamy, 653 688. New York, NY: Marcel Dekker, Inc.

Gorinstein, S., Zemser, M., Weitz, M., Halevy, S., Deutsch, J., Tilus,K., Feintuch, D., Guerra, N., Fishman, M., \& E. Bartnikowska, (1994). Fluorometric analysis of phenolics in Persimmons. Biosci. Biotechnol. Biochem., 58, 1087-1092.

Gujska, E. and K. Khan, (1991). Functional properties of extrudates from high starch fractions of navy and pinto beans and corn meal blended with legume high protein fractions. J. Food Sci., 56: $431-435$.

Guy, R. (2001). Extrusion cooking: technologies and applications, Woodhead Publishing, ISBN 978-185-5735-59-0, p.151 Cambridge, United Kingdom.

Hagenimana, A.; Ding, X. and T. Fang, (2005). Evaluation of rice flour modifided by extrusion cooking. J. Cereal Sci., 24: 1-9.

Hussain, A., Dhin, C.S., Clayton, J.T.P. and C.F. Ihitney, (1972). Mathematical simulation of mass and heat transfer in high moisture foods. Trans ASAE. 15:732-736.

Jayaraman, K. and D. Gupta, (2006). Drying of fruits and vegetables. In Mujumdar, A. S. (Ed.), Handbook of Industrial Drying (third edition). Pp 606-634. UK: Taylor and Francis. 
Kim, S.;Lee, K.; Park, J.; Lee, H. and I. Hwang, (2006). Effect of drying in antioxidant activity and changes of ascorbic acid and colour by different drying and storage in Korean red pepper (Capsicum annuum, L.). Inter. J. Food Sci. and Techno., 41(1): 90-95.

Kramer, A. and B. Twigg, (1970). Quality control for the food industry. $3^{\text {th }}$ Ed., Vol. 1. The AVI Publishing Co., Inc, USA.

Levi, A.; Ben-Shalom, N.; David, P. and R. David, (1988). Effect of blanching and drying on pectin constituents and related characteristics of dehydrated peaches. J. Food Sci., 53(4): 11871190 .

Lewicki, P. ; Vule, H.and Pamaranska- W.Lazuka, (2002). Effect of pre-treatment on convective drying of tomatoes. J. Food Eng., 54: 141-146.

Marfil, P., Santos, E. and V. Telis, (2008). Ascorbic acid degradation kinetics in tomatoes at different drying conditions. LWT-Food Sci. and Techn., 41: 1642- 1647.

Matthey, F. and M. Hanna, (1997). Physical and functional properties of twin screw extruded whey protein concentrate corn starch blends. LWT - Food Sci. Technol., 30: 359 - 366.

Mattuk, H.; Ahmed, A.; Hamed, A. and El- M. Sadawy, (1997). Production and evaluation of guava powder. Egyp. J. Appl. Sci., 12: $195-216$.

Mercier, C. and P.Feillet, (1995). Modification of carbohydrate components by extrusion cooking of cereal products. Cereal Chem., 72(3): 283-297.

Moraru, C. and J.Kokini, (2003). Nucleation and expansion during extrusion and microwave heating of cereal foods. Comprehensive Reviews in Food Sci. and Food Saf., 2: 147 - 165.

Mujumdar, A.S. (1987). Handbook of Industrial Drying. Marcel Dekker, New York.

Nagata, M. and I.Yamashita, (1992). Simple method for simultaneous determination of chlorophyll and carotenoids in tomato fruit. J. Japan Soc Food Technol., 39 (10):925-8. 
Noguchi, A.; Kugimiya, W.; Haque, Z. and K. Saio, (2001). Physical and chemical characteristics of extruded rice flour and rice flour fortified with soybean protein isolate. J. Food Sci., 66 (1): 240245.

Owureku-Asare, M.; Agyei-Amponsah, J.; Saalia, F.; Alfaro, L.; Espinoza-Rodezno, L. and Sathivel, S. (2014). Effect of pretreatment on physicochemical quality characteristics of a dried tomato (Lycopersicon esculentum). African J. Food Sci., 8(5): $253-259$.

Ranganna, S. (1979). "Manual of analysis of fruit and vegetable products". Tata McGraw Hill Publishing Co. Ltd., New Delhi.

Sharma, G.; Verma, R.and P.Pathare, (2005). Mathematical modeling of infrared radiation thin layer drying of onion slices. J. Food Eng., 71, 282-286.

Sheshma, J. and Raj, J. (2014). Effect of pre-drying treatments on quality characteristics of dehydrated tomato powder. Inter. J. Res. in Eng. \& Adv. Tech., 2(3): 1 - 7.

Stahl, W. and Sies, H. (1992). Uptake of lycopene and its geometrical isomers is greater from heat-processed than from unprocessed tomato juice in humans. J. Nutrition, 122, 2161-2166.

Schiffmann, F. (1992). Microwave processing in the US food industry. Food Tech., 56: $50-52$.

Singh, U.; Jain, S.; Doshi, A.; Jain, K. and K. Chahar, (2008). Effects of Pretreatments on Drying Characteristics of Button Mushroom. Inter. J. Food Eng., Volume 4, Issue 4. The Berkeley Electronic Press.

Strahm, B.S. (2000). Preconditiong. In: Extruders in food applications, M. N. Riaz, (Ed.), pp. 115 - 126, CRC Press, ISBN 978-1566767-79-2, Boca Raton, U. S. A.

Souza, J.; Medeiros, M. ; Magalhaes, M.; Rodrigues, S. and F. Fernandes (2007). Optimization of osmotic dehydration of tomatoes in a ternary system followed by air drying. J. Food Eng., 83: 501-509. 
Tayel;S,Ghanem.T, EL-messery A. and M.badr (2012). Modelling microwave / :convection dryer for drying of potato slices.Misr.J.Agr.Eng. vo 129 No 4 : 1377-1398

Togrul, I. and Pehlivan, D. (2002). Mathematical modeling of solar drying of apricots in thin layers. J. Food Eng., 55: 209 - 216.

Van Arsdel, W. Copley, M. and Morgan, A. (1973). "Food Dehydration" Vol.II $2^{\text {nd }}$ Ed. Practices and Application. The AVI Pub. Co. Inc., Westport, Connecticut, U.S.A.

Yaldiz, O. (2001). Effect of drying properties on drying characteristics of carrot and leek. In: Proceedings of the $20^{\text {th }}$ National Congress on Agricultural Mechanization, Sanliurfa, Turkey (in Turkish).

Yanniotis, S.; Petraki, A. and E. Soumpasi, (2007). Effect of pectin and wheat fibers on quality attributes of extruded cornstarch. J. Food Eng., 80: 594-599.

Wang, N. and R.Toews, (2010). Certain physicochemical and functional properties of fibre fractions from pulses. Food Research International. 44, 2515-2523.

Zhuang, X.; Lu, Y. and G.Yang, (1992). Extraction and determination of flavonoid in ginkgo. Chinese Herbal Medicine, 23: 122-124.

الملخص العربي

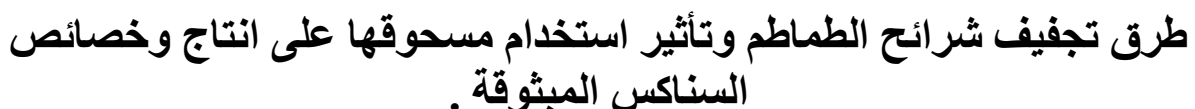

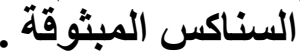

سامية الصافى فرج' ، رباب حسن عبد الرازق ، ،مر شحات يونسّ و سماح امين طه؛

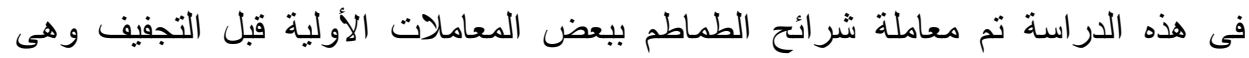

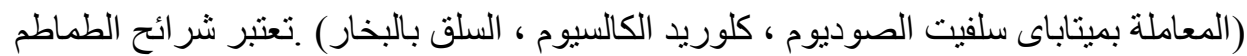

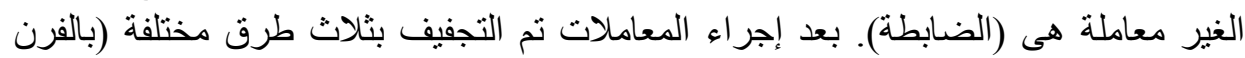

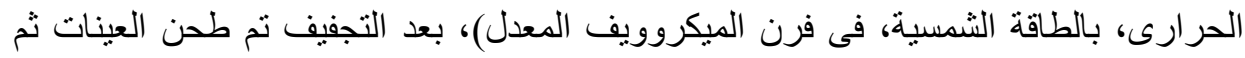
التعبئة فى عبو ات متعددة الطبقات (بولى إيسنر - ألمنيوم - بولى إيثيلين منخفض الكنئ الكثافة ).

\footnotetext{
(1) استاذ ورئيس قسم علوم وتكنولوجيا الاغذية ـ كلية الأقتصاد المنزلى - جامعة الأزهر.

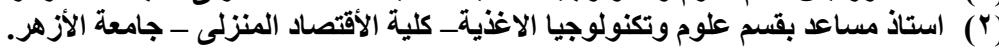

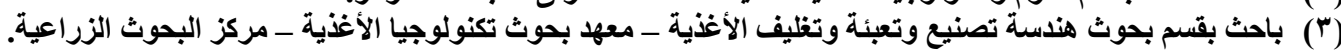

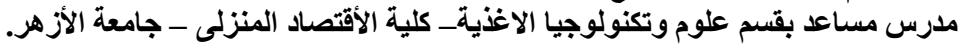




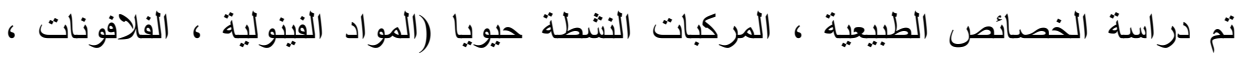

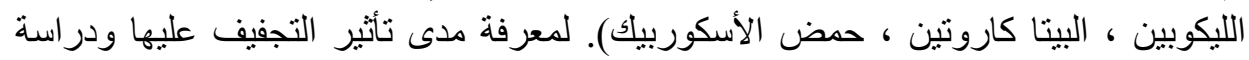

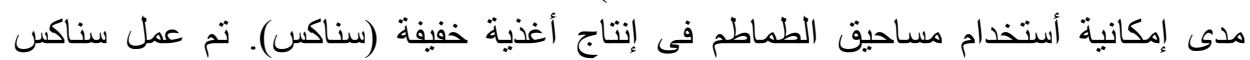

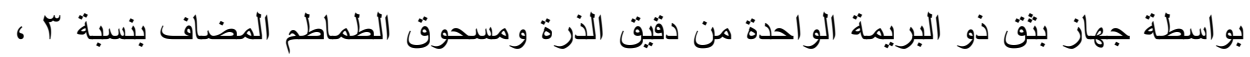

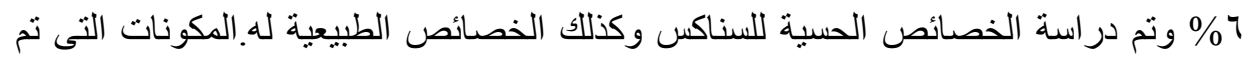

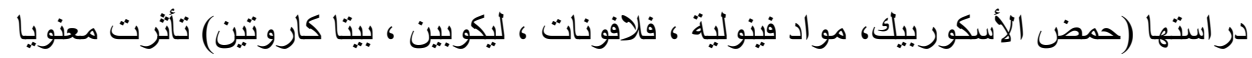

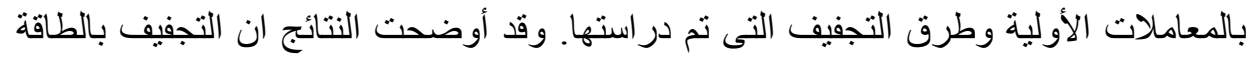

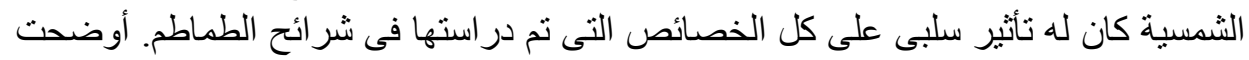

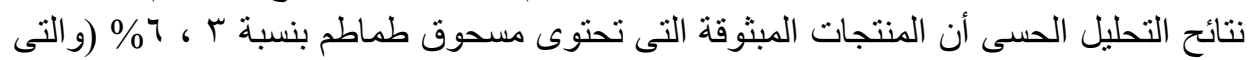

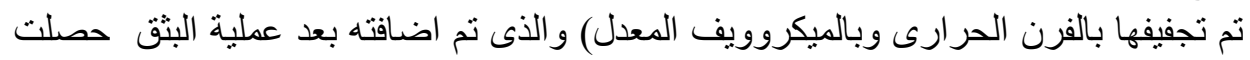

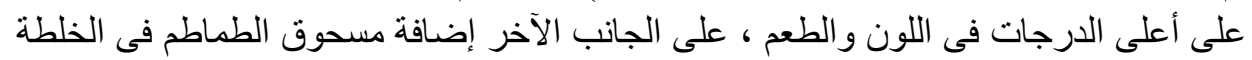

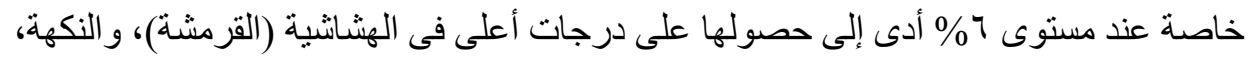

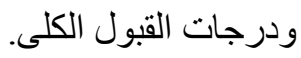

